\title{
O Bożenie Chrząstowskiej i naszej papierowej „Polonistyce”
}

\section{On Bożena Chrząstowska and our journal „Polonistyka" in the print version}

\author{
Seweryna Wysłouch \\ Uniwersytet im. Adama Mickiewicza w Poznaniu
}

\begin{abstract}
The paper presents Bożena Chrząstowska's activity as the editor-inchief of "Polonistyka", a journal of Polish studies, in 1992-2014. The point is to describe Chrząstowska's own, unique concept of a journal dedicated to postgraduate professional educators of teachers of Polish language. "Polonistyka" was supposed to make its target readers familiar with new developments in linguistics and literary studies (this task was performed by the section entitled "Horyzonty polonistyki" [Horizons of Polish studies]). Moreover, the journal provided teachers with teaching materials useful at school (the section "Tajniki warsztatu" [The secrets of didactic methods]).

The author describes Bożena Chrząstowska's inspiring role and traces the history of the journal. Within just fifteen years, "Polonistyka" has been sold three times. In 2015, after being ignored, by the fourth owner of the journal in a row, the editorial stuff established a new online journal "Polonistyka. Innowacje" (www.pressto.amu.edu.pl) with Maria Kwiatkowska-Ratajczak as the editor-in-chief.
\end{abstract}

Key words: Bożena Chrząstowska, „Polonistyka” (1992-2014)

Streszczenie: Artykuł przedstawia działalność Bożeny Chrząstowskiej jako redaktorki „Polonistyki” w latach 1992-2014. Charakteryzuje autorski model pisma, które miało na celu kształcenie merytoryczne nauczycieli-polonistów, zapoznanie ich z nowymi trendami w literaturoznawstwie i językoznawstwie (takie zadanie pełnił dział „Horyzonty polonistyki”) oraz dostarczanie im materiału do wykorzystania w szkole („Tajniki warsztatu”).

Autorka pisze o inspirującej roli Chrząstowskiej i o dziejach pisma, które w ciągu 15 lat trzy razy było sprzedawane. W 2015 r. redakcja, zignorowana przez czwartego właściciela, stworzyła w Internecie nowe pismo: „Polonistyka. Innowacje” (www.pressto.amu. edu.pl), którym kieruje Maria Kwiatkowska-Ratajczak.

Słowa kluczowe: Bożena Chrząstowska, „Polonistyka” (1992-2014)

Bożena Chrząstowska prawie ćwierć wieku była redaktorką naczelną „Polonistyki”. I to w latach 1992-2014, kiedy zespoły redakcyjne zmieniały się jak w kalejdoskopie, a pisma miały krótki żywot. I te dwadzieścia lat z okładem domaga się osobnej refleksji. Pisała o nich Jubilatka w wydanym razem 
z córką, Joanną Ciechanowską-Barnuś, Dwugłosie z życia wziętym, poświęcając jej cały rozdział $P$ jak „Polonistyka” (Chrząstowska, CiechanowskaBarnuś 2015, 207-227). Autorka skoncentrowała się tam na jednym głównie problemie: walce o reformę edukacji, w której „Polonistyka” - za Jej sprawą - była mocno zaangażowana. Była to wówczas najważniejsza społecznie kwestia: likwidacja wieloletnich zaniedbań w szkolnictwie, zmiana modelu nauczania, opracowanie nowych programów i podręczników. Nie było to łatwe ani proste, bo cały ministerialny aparat był zmianom przeciwny. Sama o tych heroicznych bojach toczonych pod sztandarem nauczycielskiej „Solidarności” pisałam z okazji 80-lecia Bożeny Chrząstowskiej (Wysłouch, 2009). Ale teraz chciałabym przypomnieć inne, zapomniane może wątki z dziejów naszej papierowej „Polonistyki”.

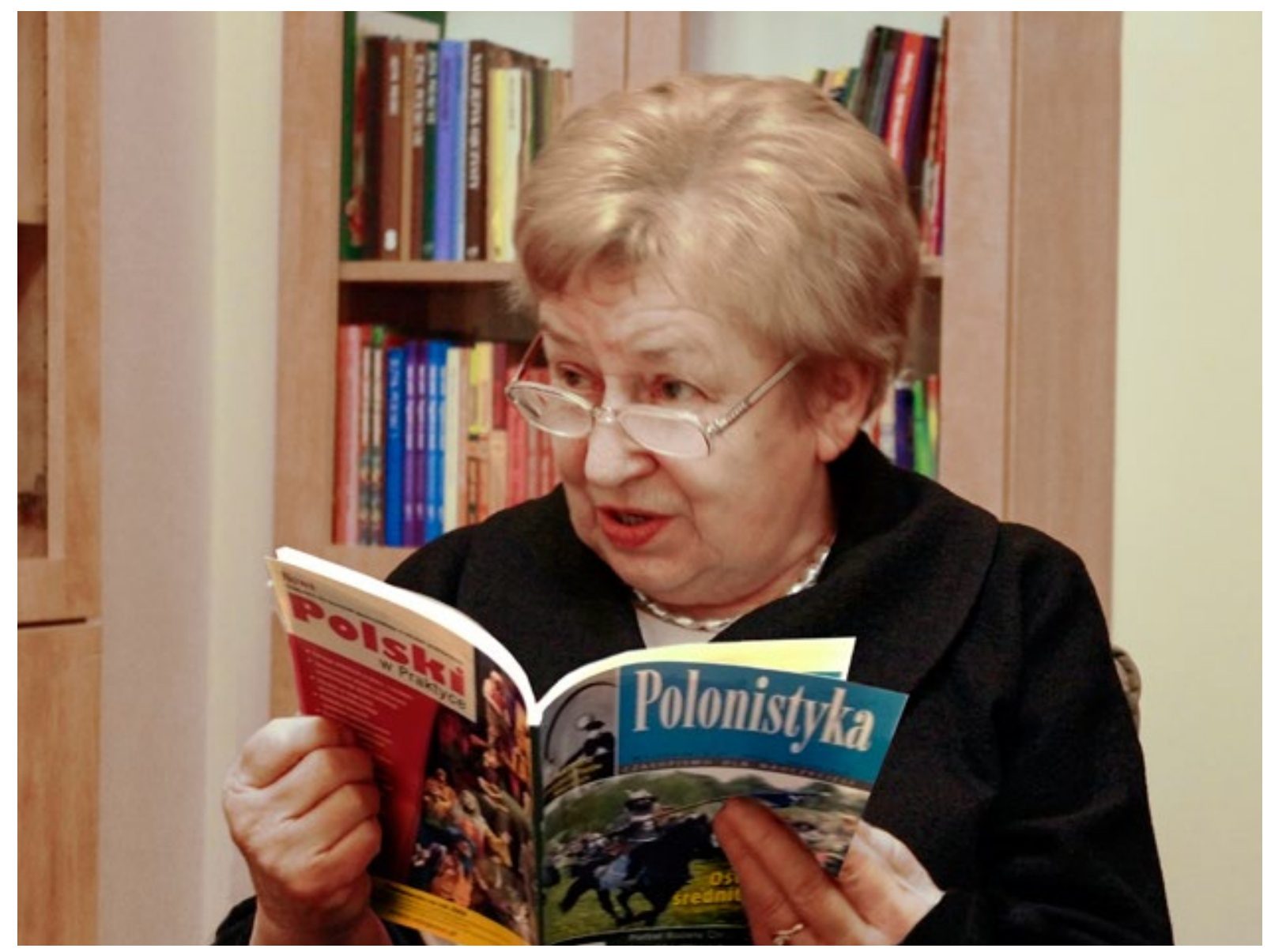

\section{Autorski model pisma}

Miesięcznik przeznaczony dla nauczycieli początkowo był własnością Ministerstwa Edukacji Narodowej, a wydawały go Wydawnictwa Szkolne i Pedagogiczne (WSiP). MEN w 1991 r. ogłosiło konkurs na redaktora naczelnego, który Chrząstowska - ku swojemu zaskoczeniu - wygrała i po nowemu zorganizowała pismo. Kształt pisma jest autorskim dziełem redaktora i tylko jego, co zawsze podkreślał Jerzy Giedroyc, i akurat w tym wypadku miał stuprocentową rację. $\mathrm{Z}$ nudnego, zideologizowanego czasopisma (Kryda, 
1995), pod rządami Bożeny Chrząstowskiej „Polonistyka” przekształciła się w atrakcyjną lekturę dla nauczycieli, studentów, olimpijczyków. Jej pracę obserwowałam z bliska, czy to jako członek kolegium redakcyjnego, czy jako „stale współpracujący”. Przede wszystkim starała się, żeby pismo nie było tylko „poznańskie”, regionalne i żeby zaktywizować nauczycieli. Zaprosiła do współpracy metodyków z innych ośrodków: Tadeusza Patrzałka z Uniwersytetu Wrocławskiego, Agnieszkę Kłakównę z Wyższej Szkoły Pedagogicznej w Krakowie oraz Alicję Kasprzycką z Warszawy (WSiP) i oni prowadzili punkty konsultacyjne w swoich miastach, w tych samych godzinach w każdy czwartek zapraszając nauczycieli do współpracy. Ale najważniejszą sprawą był profil pisma, które według Niej miało dwa podstawowe zadania: kształcić nauczycieli, dostarczać im wiedzy merytorycznej, którą mogliby wykorzystać w swojej pracy i aktywizować, podsuwając nie konspekty lekcji („gotowce”), ale wzory różnych rozwiązań metodycznych. Dlatego w piśmie wprowadziła dwa podstawowe działy: „Horyzonty polonistyki", prezentujące to, co nowego działo się w nauce o literaturze i w nauce o języku, oraz „Tajniki warsztatu”, czyli materiały o charakterze analitycznym, które można by wykorzystać w szkole.

\section{Kształcenie polonistyczne}

Dwa podstawowe działy „Polonistyki” informowały o zasadniczej idei pisma, którą było kształcenie merytoryczne, zasypanie rozziewu między wiedzą uniwersytecką a polonistyką szkolną, aby tą drogą walczyć z rutyną i inspirować nauczycieli. Dlatego „Horyzonty polonistyki” były tak ważne i ważne było, by zabierali tam głos uczeni z dużym autorytetem. Dział ten Bożena Chrząstowska prowadziła znakomicie. Była niesłychanie aktywna, uczestniczyła w różnych gremiach, jeździła na liczne konferencje: literaturoznawcze i metodyczne, zabierała głos w dyskusjach, dużo pisała - była w środowisku polonistycznym znana i ceniona, toteż potrafiła ściągnąć do „Polonistyki” „najlepsze” nazwiska: Teresę Kostkiewiczową, Henryka Markiewicza, Stefana Morawskiego, Marię Jasińską-Wojtkowską, Mariana Maciejewskiego, Małgorzatę Czermińską, Martę Wykę, Stefana Chwina, Agatę Bielik-Robson, Stanisława Gajdę, Jana Miodka - i wielu innych.

Wprowadziła monografizację numerów i wyznaczała osobę prowadzącą, która miała zadanie czuwać nad całością i napisać wstępniak, informujący czytelnika o zawartości. Pierwszy numer (opracowany głównie przez nią samą) był poświęcony Gustawowi Herlingowi-Grudzińskiemu, który w 1991 r. - po 50 latach - mógł przyjechać do Polski („Polonistyka” 2/1992). I kiedy dziś go oglądam, nie mogę wyjść z podziwu. W „Horyzontach polonistyki” znajdujemy materiały z uroczystości nadania doktoratu honoris causa UAM (przemówienie Herlinga na temat literatury emigracyjnej oraz charakterystyke jego twórczości), w „Tajnikach warsztatu” - trzy teksty o pracy nad Wieża w szkole. Są także „Spotkania” przynoszące relacje z pobytu 
Herlinga w Poznaniu i w rodzinnych Kielcach, a także recenzje trzech książek, które się o nim ukazały. Jest także "Giełda pomysłów” traktująca o wycieczce śladami Herlinga po ziemi kieleckiej i o wykorzystaniu do interpretacji Wieży ilustracji Jana Lebensteina. Na wewnętrznych stronach okładek duże zdjęcie Herlinga w todze i list pisany ręcznie do Ryszarda K. Przybylskiego (z 28 I 1984) o opowiadaniach, przesłoniętych przez Inny Świat. Numer ukazał więc Herlinga wielostronnie: dostarczał wiedzy merytorycznej o jego twórczości, orientował w stanie badań, podsuwał rozwiązania metodyczne, a nawet umożliwiał kontakt z dokumentem osobistym - listem pisarza. Czegóż chcieć więcej? Jedno się nie udało. Na marnym papierze bardzo źle wyszły zamieszczone wewnątrz numeru fotografie. Ale na papier i jakość ilustracji nie mieliśmy żadnego wpływu.

„Personalne” numery monograficzne miały wypełnić białe plamy w nauczycielskiej edukacji, zwykle bywały związane z aktualnymi wydarzeniami. Bohaterami byli (często wielokrotnie) Miłosz, Szymborska, Herbert, Barańczak, Schulz, Gombrowicz, a także poetki zapomniane, pisarze niedocenieni (Orzeszkowa) czy literatura światowa (np. nobliści). W trosce o czytelnictwo i orientację w bieżącym życiu literackim „Polonistyka” zamieszczała również „Przeglądy prasy” i wydawała numery dodatkowe, poświęcone nowościom wydawniczym, a przede wszystkim reformie edukacji: nowej maturze i zawzięcie dyskutowanym $\mathrm{w}$ latach 90. programom szkolnym.

Ale znacznie częściej pismo koncentrowało się na zagadnieniach polonistycznych, którymi żyła nauka o literaturze, jak biografia i autobiografia, filozofia i literatura, integracja nauki o literaturze z nauką o języku, różne szkoły interpretacji, intertekstualność, korespondencja sztuk, problemy literackiego przekładu, sacrum w literaturze, esej, małe ojczyzny, Holokaust, antropologia literatury, sport, literatura popularna, komiks, film, teatr, nowe media i wiele innych. Były też numery usiłujące odświeżyć wiedzę o epokach, opracowywane pod hasłem „epoki na nowo odczytane”. Najciekawsze i najważniejsze materiały z lat 1992-1996 Bożena Chrząstowska przedrukowała w 2 tomach wydanych przez WSiP pod tytułem Kompetencje szkolnego polonisty (Chrząstowska (red.), 1995, 1997). Teksty zgrupowała w trzech działach: „Ku szkole otwartej”, „Z metodologii” i „Z metodyki”. Żałowałam, że w następnym dziesięcioleciu nie powstały kolejne zbiory. Bożena wszystko we WSiP-ie umiała załatwić: pieniądze na konkurs, na dodatkowe numery „Polonistyki”, na prace zbiorowe. Cechował Ją entuzjazm dla sprawy i ogromna siła perswazji. Nikt się jej nie oparł. Szła jak burza - walczyła o reformę edukacji, pisała podstawy programowe dla różnych poziomów kształcenia, podręczniki dla szkół średnich, organizowała konferencje, spotkania polsko-niemieckie (w ramach Guardini Stiftung), a w międzyczasie wydawała własne książki i zdobywała kolejne stopnie naukowe. Nic dziwnego, że nie miała głowy na „powtórki” i robienie kolejnych tomów Kompetencji szkolnego polonisty. To, że przy tym „Demonie Ruchu” „Polonistyka” się nie 
rozsypała, nie rozpadła, nie zawaliła wszystkich możliwych terminów i nie została przez WSiP rozpędzona na cztery wiatry, zawdzięczamy dzielnemu sekretarzowi, Michałowi Ratajczakowi, który zapewniał jej stabilność, był ostoją spokoju i z żelazną konsekwencją egzekwował materiały, by kompletować kolejne numery. A nie było to proste...

Monografizacja wymagała zamawiania artykułów zsynchronizowanych $\mathrm{z}$ wiodącym tematem czy problemem. Wprawdzie redakcja bardzo się starała, żeby autorzy byli z różnych ośrodków, ale baza była w Poznaniu, tu powstawały pomysły, „obgadywało się” temat, szukało autorów - miejscowych i zamiejscowych. Bożena najczęściej była inspiratorką problematyki, ale była również otwarta na inne propozycje i na numery opracowane przez inne ośrodki. Po latach wydając swój tom interpretacji, przekonałam się, ile tekstów napisałam specjalnie dla "Polonistyki” (Wysłouch 2015, 265), które inaczej nigdy by nie powstały. Ale inspirująca rola Chrząstowskiej to nie wszystko. Uczyła pisania. W „Polonistyce” często debiutowali ludzie młodzi i ołówek redaktora stanowił przykład pracy nad tekstem. Bo najłatwiej jest tekst odrzucić, ale cała sztuka polega na tym, by przekonać autora do dalszej pracy i wskazać, co i jak ma poprawić. Raz nawet któryś z debiutantów - ku zdumieniu Naczelnej - rozełkał się w telefon podczas takiej roboczej, redakcyjnej rozmowy. Naczelna umiała inspirować, umiała korygować teksty i - umiała stworzyć zespół, dla którego pismo było ważne. To była nasza „Polonistyka”.

\section{WSiP}

W 1999 r. MEN pozbył się czasopism, informując lojalnie o tym redaktorów. Właścicielem tytułu został WSiP, ale u nas to przeszło bez wrażenia. W zasadzie nic się nie zmieniło. Bożena stale walczyła z administracją i odnosiła także na tym polu sukcesy. Redakcja merytoryczna była w Poznaniu, a techniczna w Warszawie. Oddawanie materiałów do wydawnictwa wyglądało tak, że pani Redaktor wraz z sekretarzem jechała porannym Lechem do stolicy z maszynopisami pod pachą, a poniektórzy autorzy przybiegali jeszcze na dworzec, żeby wręczyć swoje do ostatniej chwili pisane arcydzieło i zapewnić jej lekturę podczas podróży. No, ale pani Redaktor wymogła, żeby skład był robiony w Poznaniu, a WSiP załatwiał tylko druk. W końcu komputeryzacja uwolniła zarząd od nerwowych wyjazdów do Warszawy.

Współpracę ze WSiPem wspominam dobrze. Co jakiś czas mieliśmy merytoryczną ocenę pisma. Wydawca zamawiał recenzje u 2 profesorów (u literaturoznawcy i u metodyka), zapraszał ich i redakcję na dyskusję. Uczestniczyłam w kilku takich posiedzeniach. Oceny literaturoznawców były bardzo dobre, natomiast powtarzały się uwagi, że za mało jest materiałów metodycznych. I to był dylemat nie do rozwiązania. Bożena bardzo się starała, żeby zwalczać „przechył akademicki”, żeby materiały nie były za trudne i żeby pamiętać o dydaktyce. Ale pismo powstawało w ośrodku 
akademickim i mimo wielu starań, konkursów na pracę metodyczną, wcześniejszej informacji o tematyce przyszłych numerów, bardzo trudno było pozyskać do współpracy nauczycieli-praktyków. Bo, jak się okazało, nauczyciele lubią mówić, ale nie lubią pisać... Zaproponowałam kiedyś, żeby redaktor prowadzący zrobił na końcu numeru coś w rodzaju „podsumowania dydaktycznego", sugerując, jak można wykorzystać w szkole przedstawione zagadnienia. Zrobiłam nawet taką próbkę, ale pomysł nie został podjęty. Inna rzecz, że podsumowanie wymagałoby refleksji nad całością, tymczasem numery były składane w ostatniej chwili i prowadzący często do końca nie wiedział, co ma, a czego nie ma i czy ewentualne luki nie zostaną wypełnione jakimś materiałem zalegającym w szufladzie redakcyjnej. Terminowość zawsze była naszą piętą Achillesową i gdyby nie talenty Michała Ratajczaka, który umiał omotać autorów i teksty wydobywać spod ziemi, żaden numer by się $\mathrm{w}$ terminie nie ukazał.

Permanentnie byliśmy niezadowoleni z okładki. Na początku okładka miała ładny napis, trochę koloru i w białym okienku lead: tytuł numeru wraz z ważniejszymi tekstami. Ale w 2000 roku WSiP wpadł na szalony pomysł, by wszystkie numery wyglądały tak samo. Na granatowym tle udającym rękopis, w okienku z chmurkami figurowało - nie wiadomo, ptasie czy gęsie? - piórko. Wewnętrzne strony okładki zajęte były przez reklamy WSiP-u. Papier był lepszy, ale straciliśmy miejsce na zapowiedź tematyki i na dobre ilustracje. Dopiero w 2003 r. zmieniło się okienko i zamiast piórka pojawiły się fotografie starodruków, a w numerze 10 - o radości - pojawiła się wreszcie kolorowa okładka, oczywiście projektowana w Warszawie.

\section{Pismo na sprzedaż z inwentarzem (żywym) lub bez}

I oto jak grom z jasnego nieba dopadła nas w 2006 r. wieść, że WSiP „nasze” pismo sprzedał. Pozbył się nierentownych czasopism, zostawiając sobie dochodowe podręczniki. „Polonistyka”, która za komuny miała 10 tysięcy nakładu, była sprzedawana w obiegu zamkniętym, prenumerowały ją głównie szkoły, zamawiając dla nauczycieli po kilka egzemplarzy. Po transformacji szkoły z oszczędności ograniczały prenumeratę albo z niej w ogóle rezygnowały. Sprzedaż malała. Równocześnie dobijało nas ksero. Nauczyciele kserowali sobie materiały, a nawet całe numery. Chrząstowska walczyła, by czasopismo trafiło do wolnej sprzedaży i nawet coś wywalczyła, numery „Polonistyki” pojawiły się w „Kapitałce” - małej księgarence przy Collegium Noum, ale to nie mogło poprawić bilansu pisma. Więc WSiP wystosował eleganckie listy z podziękowaniem za współpracę i z informacją o nowym właścicielu, którym został pan Josef Raabe, wydawca czasopism pedagogicznych (spółka „Edupress”). Byliśmy zaskoczeni i zdezorientowani. Numer 1/2006 wyszedł pod firmą WSiP-u, numer 2, poświęcony literaturze dziecięcej, był w druku (wyszedł już pod firmą Raabe), a co z numerem 3 ? Akurat ja go przygotowywałam, miał tytuł Architektura i literatura i nie wiadomo było: robić czy go nie robić? A jeśli materiały nie pójdą do druku, 
to w jakiej sytuacji stawiamy się wobec autorów? Zmarnujemy ich wysiłek i pracę. Miejscowi może zrozumieją, ale zamiejscowi? Jednak Naczelna kazała robić - i miała rację. Pan Raabe nie ingerował w redakcję, nie obchodziły go sprawy merytoryczne. W ciągu 8 lat, kiedy był właścicielem „Polonistyki”, postarał się o lepszy papier, powiększył format, wywindował w górę cenę, a w końcu pismo po cichu sprzedał, nie siląc się na żadne podziękowania. Ostatnim, przygotowanym przez Wiesię Wantuch numerem była poświęcona filmowej animacji, luksusowo wydana Magia filmu animowanego, którą już firmował nowy właściciel - Forum Media Polska („Polonistyka” 10/2014).

W ten sposób pismo sprzedane zostało po raz trzeci. W ciągu 15 lat trzykrotnie zmieniało właściciela, ale zespół redakcyjny zawsze pozostawał bez zmian, akceptowały go MEN, WSiP i nawet Josef Raabe. Nowy, czwarty właściciel potraktował nas jak zbędny inwentarz. Miał swoich pracowników i własne plany. Dlatego „stara” redakcja przeniosła się do Internetu i stworzyła pismo, nawiązujące w tytule do tradycji: „Polonistyka. Innowacje". Bożena Chrząstowska, jak zawsze zbuntowana i jak zawsze otwarta na to, co nowe, patronowała internetowej rewolucji, ale ze względu na wiek i stan zdrowia wycofała się z redakcji. Pałeczkę przejęła jej uczennica i wieloletnia redakcyjna współpracowniczka, która pismo prowadzi już czwarty rok - Maria Kwiatkowska-Ratajczak (Kwiatkowska-Ratajczak 2015). Powodzenia, Marysiu!

\section{Bibliografia:}

Chrząstowska Bożena (red.), 1995, Kompetencje szkolnego polonisty. Szkice i artykuły $z$ metodyki, Warszawa.

Chrząstowska Bożena (red.), 1997, Kompetencje szkolnego polonisty 2. Szkice i artykuły z metodyki z lat 1994-1996, Warszawa.

Chrząstowska Bożena, Ciechanowska-Barnuś Joanna, 2015, Dwugłos z życia wzięty (rozdział P jak „Polonistyka”), Poznań, s. 207-227.

Kryda Barbara, 1995, Szkic do monografii „Polonistyki” (refleksje nie tylko historyczne), „Polonistyka”, nr 2, s. 69-79.

Kwiatkowska-Ratajczak Maria, 2015, Nowe pismo, dawna linia redakcyjna, www.pressto.amu.edu.pl „Polonistyka. Innowacje”, nr 1, s. 1-4.

Wysłouch Seweryna, 2009, Heroiczne początki. O prof. Bożenie Chrzastowskiej, „Polonistyka”, nr 1, s. 6-9.

Wysłouch Seweryna, 2015, Narracje małe i duże, Poznań.

\section{O Autorce:}

Seweryna Wysłouch - prof. dr hab.; emerytowany pracownik Instytutu Filologii Polskiej UAM. Autorka prac z zakresu prozy polskiej XX w.: Proza Michała Choromańskiego (1977), Problematyka symultanizmu w prozie (1981), Narracje małe i duże (2015); z dziedziny semiotyki literatury i sztuk plastycznych: Literatura a sztuki wizualne (1994), Literatura 
i semiotyka (2001); Wyprzedaż semiotyki, pod red. M. Brzóstowicz-Klajn i B. Kaniewskiej (2011), a także z dydaktyki literatury. Współautorka napisanej z B. Chrząstowską Poetyki stosowanej (1978, 1987, 2000) oraz napisanego z B. Chrząstowską i E. Wiegandtową podręcznika dla maturzystów Literatura współczesna $(1992,1993,1997)$ i poradnika metodycznego W klasie maturalnej. Ksiażka nauczyciela-polonisty (1999). 